\title{
EXTRACORPOREAL SHOCKWAVE THERAPY IN SHOULDER INJURIES: PROSPECTIVE STUDY
}

\section{USO DE TERAPIA DE ONDAS DE CHOQUE EM DOENÇAS ORTOPÉDICAS DO OMBRO: ESTUDO PROSPECTIVO}

\author{
Victor Otavio Moraes de Oliveira ${ }^{1}$ (1), Juliana Munhoz Vergara ${ }^{1}$ (1), Vicente Furquim de Oliveira ${ }^{1}$ (D), \\ Paulo Henrique Schmidt Lara ${ }^{1}$ (1), Luiz Carlos Nogueira Júnior ${ }^{1}$ (i), Gustavo Gonçalves Arliani ${ }^{1}$ (1)
}

1. Orthopedics and Traumatology Group of Prevent Senior, São Paulo, SP, Brazil.

\section{ABSTRACT}

Objective: To evaluate the functional results after the use of extracorporeal shockwave therapy (ESWT) in four groups of patients: tendinopathy, partial rotator cuff injury, adhesive capsulitis and calcareous tendinopathy of the rotator cuff at one month and three months after the end of treatment. Methods: Case series in which patients were evaluated according to the VAS of pain, range of motion of the shoulder, and functional questionnaires DASH and modified UCLA. Results: There was a significant increase in the measure of flexion, lateral rotation and shoulder abduction in the evaluations after treatment in relation to the baseline measurement $(p<0.001)$ and no evidence of significant difference was found between the post-treatment evaluations at one month and three months follow-up $(p>0.05)$. There was a significant reduction in the VAS score, increase in the UCLA score and a significant reduction in the DASH score in the post-treatment evaluations in relation to the baseline score $(p<0.001)$ and a significant improvement in the three-month evaluation in relation to one month $(p<0.05)$. Conclusion: Extracorporeal shockwave therapy proved to be efficient and safe in the treatment of shoulder pathologies, improving pain, range of motion and functional scores in all groups of patients evaluated in the study. Level of Evidence IV, Case series.

Keywords: Shoulder Injuries. Shoulder. Extracorporeal Shockwave Therapy.

\section{RESUMO}

Objetivo: Avaliar os resultados funcionais após uso de terapia de ondas de choque (TOC) em quatro grupos de pacientes: tendinopatia, lesão parcial de manguito rotador, capsulite adesiva e tendinopatia calcária do manguito rotador com 1 mês e 3 meses após término do tratamento. Métodos: Série de casos, na qual os pacientes foram avaliados de acordo com a EVA da dor, amplitude de movimento do ombro, e questionários funcionais DASH e UCLA modificados. Resultados: Houve aumento significativo das medidas de flexão, rotação lateral e abdução do ombro nas avaliações após tratamento, em relação à medida basal $(p<0,001)$ e não houve evidências de variação significativa entre as avaliações pós-tratamento com 1 mês e 3 meses de acompanhamento $\left(p^{\circ}>0,05\right)$. Houve redução significativa do escore EVA, aumento do escore UCLA e redução significativa do escore DASH nas avaliações após tratamento em relação ao escore basal $(p<0,001)$ e melhora significativa na avaliação de três meses em relação a um mês $(p<0,05)$. Conclusão: A terapia de ondas de choque mostrou-se uma terapia eficiente e segura no tratamento das patologias do ombro, com melhora da dor, arco de movimento e escores funcionais em todos os grupos de pacientes avaliados no estudo. Nível de Evidência IV, Série de casos.

Descritores: Lesões do Ombro. Ombro. Tratamento por Ondas de Choque Extracorpóreas.

Citation: Oliveira VOM, Vergara JM, Oliveira VF, Lara PHS, Nogueira LC Jr, Arliani GG. Extracorporeal shockwave therapy in shoulder injuries: prospective study. Acta Ortop Bras. [online]. 2021;29(5):268-273. Available from URL: http://www.scielo.br/aob.

\section{INTRODUCTION}

Pain complaints that affect the shoulder girdle region are common causes of orthopedic appointments. ${ }^{1}$ Among the most common diseases, we mainly have conditions that affect the rotator cuff, such as tendinopathies, partial rotator cuff injuries, calcareous tendinopathies, and adhesive capsulitis. ${ }^{2}$ Conservative treatment with medications, physical therapy, acupuncture, anesthetic blocks, and corticosteroid injections is usually the initial treatment and is effective in most cases. ${ }^{3,4}$ However, patients resistant to primary treatment are not always willing or in good clinical condition for surgical treatment, which, in turn, does not always guarantee good results.

The use of alternative therapies, such as shockwave therapy, has been reported with good results in certain groups of patients. ${ }^{5-8}$ However, there is still no consensus in the literature about protocols and specific diseases where shockwave therapy is effective. The use of shockwave therapy applied to the musculoskeletal system in Brazil began in 1998 with the arrival of the first urological lithotripsy machines, which were adapted

All authors declare no potential conflict of interest related to this article.

The study was conducted at the Orthopedics Institute of Prevent Senior.

Correspondence: Paulo Henrique Schmidt Lara. Rua José Oscar de Abreu Sampaio, 368, São Paulo, SP, Brazil, 03337020. phslara@gmail.com 
for use in orthopedic injuries. This adaptation consisted in the introduction of a new technology that allowed to grade the depth and force with which shock waves penetrate the human body. ${ }^{5}$ The action is determined by the penetration of mechanical waves into tissues, without damage to the skin, vessels and nerves. Upon reaching the injured site, the shock waves promote a mechanical stimulus that induces a series of biological effects, such as: increased production of prostaglandins related to the tissue repair process; increased congestion and local blood microcirculation and increased local nitric oxide concentration with pain relief. ${ }^{9-12}$ Thus, the aim of this study is to evaluate the functional outcomes after the use of shockwave therapy (SWT) in four groups of patients: tendinopathy, partial rotator cuff injury, adhesive capsulitis, and rotator cuff calcareous tendinopathy with one month and three months after the end of treatment.

\section{MATERIALS AND METHODS}

This is a prospective study with four groups of patients with the following diseases: 1. Rotator cuff tendinopathy; 2. Shoulder adhesive capsulitis; 3 . Calcareous tendinopathy of the shoulder; 4. Partial rotator cuff injury. The Study was submitted and approved by the institution's research ethics committee (number 27245219.8.0000.8114). All patients over 18 years of age were selected from the general orthopedic and shoulder clinic of Prevent Senior and treated between 01/01/2018 and 04/30/2018, with diagnoses confirmed by imaging exams (radiographs, ultrasonography and/or magnetic resonance), who have failed conventional conservative treatment for at least three months. The patient sample was estimated using a 95\% confidence interval and $80 \%$ power to detect a 15-point difference in the DASH score, with a standard deviation of 10 to 18 in each group and allowing a loss of approximately $20 \%$ of patients. In this way we recruited a total of at least 15 individuals in each group.

Patients were evaluated according to the VAS $^{13}$ (visual analogue scale) of pain, range of motion (anterior elevation, medial rotation, lateral rotation and abduction) of the shoulder, and functional DASH ${ }^{14}$ and modified UCLA questionnaires. ${ }^{15}$ Three shockwave therapy sessions were carried out in each patient, with an interval of seven days each, and reassessments after one and three months after the last session. The shockwave therapy sessions were performed by three physicians with prior training in the technique and members of the Brazilian Medical Society of Shockwave Therapy (SMBTOC). All sessions were performed by the same physician.

\section{Inclusion criteria}

- Patients over 18 years old, without distinction of age or gender;

- Present a diagnosis of rotator cuff tendinopathy or partial lesion that affects less than $50 \%$ of the thickness or adhesive capsulitis or rotator cuff calcareous tendinopathy;

- Diagnostic confirmation through magnetic resonance;

- Availability of follow-up during the study period (three months);

- Having undergone previous conservative treatment without improvement of symptoms for a minimum period of three months;

- Having signed an informed consent form to participate in the study (Annex 5).

\section{Exclusion criteria}

- Previous surgery on the affected shoulder;

- Injury greater than $50 \%$ of the thickness of the rotator cuff;

- Adhesive capsulitis secondary to fracture of the shoulder girdle;

- Secondary osteoarthritis;

- Treatment with corticosteroids in the last two months.

\section{Statistical analysis}

Descriptive statistical analysis of each of the analyzed parameters was performed. Parametric statistical tests were used, as the data are quantitative and continuous. To compare the quantitative variables, the ANOVA test was used. Differences with $p<0.05$ were considered to be statistically significant.

\section{RESULTS}

The study sample consisted of 60 patients, of which 6 (six) abandoned the study before the evaluation one month after the first application. Of these six patients, one underwent surgical treatment due to the lack of improvement in the partial cuff lesion before completing the three-month follow-up. The remaining patients (five) started the shockwave therapy, but before the end of the three sessions, they chose to continue with the conservative treatment with medication and physical therapy. We did not observe side effects and complications related to the technique in the patients included in the study. Thus, the results observed in 54 patients with shoulder injury treated with Shockwave Therapy, with first application between May and August 2018, were analyzed.

Participants (Table 1) were aged between 51 and 92 years, with a mean of 63.6 years (SD $=7.5$ years). The diagnoses and duration of symptoms before the beginning of the study and the presence of comorbidities of the patients are also shown in Table 1.

\begin{tabular}{|c|c|}
\hline Age (years) & $\mathrm{n}=54$ \\
\hline mean $(S D)$ & $63.6(7.5)$ \\
\hline median (Q1; Q3) & $62(58 ; 67)$ \\
\hline minimum, maximum & $51 ; 92$ \\
\hline \multicolumn{2}{|l|}{ Age group } \\
\hline 50 to 59 years & $17(31.5 \%)$ \\
\hline 60 to 69 years & $28(51.9 \%)$ \\
\hline 70 years or older & $9(16.7 \%)$ \\
\hline \multicolumn{2}{|l|}{ Gender } \\
\hline Male & $13(24.1 \%)$ \\
\hline Female & $41(75.9 \%)$ \\
\hline \multicolumn{2}{|l|}{ Diagnostic } \\
\hline MR tendinopathy & $12(22.2 \%)$ \\
\hline MR partial injury & $18(33.3 \%)$ \\
\hline Adhesive capsulitis & $12(22.2 \%)$ \\
\hline Calcific tendonitis & $12(22.2 \%)$ \\
\hline \multicolumn{2}{|l|}{ Affected side } \\
\hline Right & $34(63.0 \%)$ \\
\hline Left & $20(37.0 \%)$ \\
\hline \multicolumn{2}{|l|}{ Dominance } \\
\hline Right & $51(94.4 \%)$ \\
\hline Left & $3(5.6 \%)$ \\
\hline \multicolumn{2}{|l|}{ Symptoms time } \\
\hline 3 to 6 months & $9(16.7 \%)$ \\
\hline 6 to 12 Months & $16(29.6 \%)$ \\
\hline 12 to 24 months & $16(29.6 \%)$ \\
\hline more than 24 months & $13(24.1 \%)$ \\
\hline \multicolumn{2}{|l|}{ Comorbidities } \\
\hline Yes & $48(88.9 \%)$ \\
\hline No & $6(11.1 \%)$ \\
\hline \multicolumn{2}{|l|}{ Surgery } \\
\hline No & 54 (100.0\%) \\
\hline
\end{tabular}

SD: standard deviation; Q1: first quartile; Q3: third quartile. 
Patients were evaluated for range of motion measurements at baseline, one month and three months after treatment (Table 2).

Table 2. Estimated mean values and confidence intervals $(95 \% \mathrm{Cl})$ during follow-up for the range of motion measurements of patients with shoulder injury treated with Shockwave Therapy.

\begin{tabular}{|c|c|c|c|}
\hline \multirow[b]{2}{*}{ Range of Motion (RM) } & \multicolumn{3}{|c|}{ Evaluation } \\
\hline & $\begin{array}{c}\text { Baseline } \\
(n=54)\end{array}$ & $\begin{array}{l}1 \text { month } \\
(n=54)\end{array}$ & $\begin{array}{c}3 \text { months } \\
(n=54)\end{array}$ \\
\hline Previous elevation $\left({ }^{\circ}\right)$ & $\begin{array}{c}121.9 \\
(112.9 ; 131.7)\end{array}$ & $\begin{array}{c}143.7 \\
(135.3 ; 152.7)\end{array}$ & $\begin{array}{c}145.7 \\
(137.4 ; 154.6)\end{array}$ \\
\hline \multicolumn{4}{|l|}{ Differences } \\
\hline 1 month - Baseline & $21.8(12.7 ; 30.9)$ & $p<0.001$ & \\
\hline 3 months - Baseline & $23.8(13.4 ; 34.2)$ & $p<0.001$ & \\
\hline 3 months -1 month & $2.0(-4.4 ; 8.5)$ & $P=0.536$ & \\
\hline Lateral rotation $\left({ }^{\circ}\right)$ & $53.5(48.4 ; 59.1)$ & $63.3(58.0 ; 69.1)$ & $64.4(58.9 ; 70.3)$ \\
\hline \multicolumn{4}{|l|}{ Differences } \\
\hline 1 month - Baseline & $9.8(2.0 ; 17.7)$ & $p=0.010$ & \\
\hline 3 months - Baseline & $10.8(2.8 ; 18.9)$ & $p=0.004$ & \\
\hline 3 months -1 month & $1.0(-2.3 ; 4.4)$ & $p=0.550$ & \\
\hline Abduction $\left({ }^{\circ}\right)$ & $72.1(67.9 ; 76.6)$ & $83.6(81.1 ; 86.2)$ & $85.0(82.6 ; 87.4)$ \\
\hline \multicolumn{4}{|l|}{ Differences } \\
\hline 1 month - Baseline & $11.5(6.4 ; 16.6)$ & $p<0.001$ & \\
\hline 3 months - Baseline & $12.9(7.4 ; 18.3)$ & $p<0.001$ & \\
\hline 3 months -1 month & $1.4(-0.6 ; 3.4)$ & $p=0.179$ & \\
\hline
\end{tabular}

We found evidence of a significant increase in the measurement of anterior elevation, lateral rotation and shoulder abduction in the post-treatment assessments compared to the baseline measurement $(p<0.001)$ and there was no evidence of significant variation between the post-treatment assessments at one month and three months follow-up ( $p>0.05$ ).

Pain and function assessment instruments were applied to patients at baseline, one month and three months after treatment (Table 3).

Table 3. Estimated mean values and confidence intervals $(95 \% \mathrm{Cl})$ during follow-up for pain and function scores of patients with shoulder injury treated with Shockwave Therapy.

\begin{tabular}{|c|c|c|c|}
\hline \multirow[b]{2}{*}{ Instrument scores } & \multicolumn{3}{|c|}{ Evaluation } \\
\hline & Baseline $(n=54)$ & $\begin{array}{l}1 \text { month } \\
(n=54)\end{array}$ & $\begin{array}{c}3 \text { months } \\
(n=54)\end{array}$ \\
\hline VAS & $6.9(6.4 ; 7.4)$ & $4.8(4.1 ; 5.5)$ & $3.4(2.7 ; 4.1)$ \\
\hline \multicolumn{4}{|l|}{ Differences } \\
\hline 1 month - Baseline & $-2.1(-2.9 ;-1.3)$ & $p<0.001$ & \\
\hline 3 months - Baseline & $-3.5(-4.4 ;-2.7)$ & $p<0.001$ & \\
\hline 3 months -1 month & $-1.4(-2.1 ;-0.8)$ & $p<0.001$ & \\
\hline UCLA & $43.3(40.3 ; 46.6)$ & $69.0(64.7 ; 73.6)$ & $74.6(68.9 ; 80.8)$ \\
\hline \multicolumn{4}{|l|}{ Differences } \\
\hline 1 month - Baseline & $25.7(20.4 ; 30.9)$ & $p<0.001$ & \\
\hline 3 months - Baseline & $31.3(24.9 ; 37.6)$ & $p<0.001$ & \\
\hline 3 months -1 month & $5.6(0.8 ; 10.5)$ & $p=0.024$ & \\
\hline DASH & $57.3(53.3 ; 61.6)$ & $40.5(35.5 ; 46.3)$ & $34.1(28.8 ; 40.3)$ \\
\hline \multicolumn{4}{|l|}{ Differences } \\
\hline 1 month - Baseline & $-16.8(-22.8 ;-10.7)$ & $p<0.001$ & \\
\hline 3 months - Baseline & $-23.2(-30.0 ;-16.4)$ & $p<0.001$ & \\
\hline 3 months -1 month & $-6.4(-11.9 ;-1.0)$ & $p=0.021$ & \\
\hline
\end{tabular}

Values expressed as estimated means and $95 \%$ confidence intervals; $p$ values corrected by the sequential Bonferroni method.
We observed evidence of a significant reduction in the VAS score, an increase in the UCLA score and a significant reduction in the DASH score in the post-treatment assessments compared to the baseline score $(p<0.001)$ and a significant improvement in the three-month evaluation compared to the one-month evaluation $(p<0.05)$.

We investigated the relation between VAS scores at baseline, one month and three months after treatment, and patient characteristics (Table 4).

Table 4. Estimated mean values and confidence intervals $(95 \% \mathrm{Cl})$ during follow-up for the VAS score according to the characteristics of patients with shoulder injury treated with Shockwave Therapy.

\begin{tabular}{|c|c|c|c|}
\hline \multirow{2}{*}{$\begin{array}{c}\text { VAS score } \\
\text { Characteristics of patients }\end{array}$} & \multicolumn{3}{|c|}{ Evaluation } \\
\hline & Baseline & 1 month & 3 months \\
\hline \multicolumn{4}{|l|}{ Gender } \\
\hline Male & $6.7(5.7 ; 7.7)$ & $4.2(3.0 ; 5.4)$ & $2.9(1.4 ; 4.5)$ \\
\hline Female & $7.0(6.4 ; 7.5)$ & $5.0(4.1 ; 5.8)$ & $3.5(2.7 ; 4.3)$ \\
\hline \multicolumn{4}{|l|}{ Comparisons } \\
\hline Male $\times$ Female & $p=0.649$ & $p=0.331$ & $p=0.506$ \\
\hline \multicolumn{4}{|l|}{ Age group } \\
\hline 50 to 59 years & $6.7(5.9 ; 7.5)$ & $4.5(3.3 ; 5.8)$ & $3.2(1.9 ; 4.5)$ \\
\hline 60 to 69 years & $7.1(6.5 ; 7.7)$ & $4.9(3.9 ; 5.8)$ & $3.8(2.8 ; 4.8)$ \\
\hline 70 years or older & $6.7(5.1 ; 8.3)$ & $4.9(3.4 ; 6.4)$ & $2.3(1.2,3.4)$ \\
\hline \multicolumn{4}{|l|}{ Comparisons } \\
\hline $50-59 a \times 60-69 a$ & $p>0.999$ & $p>0.999$ & $p=0.598$ \\
\hline $50-59 a \times \geq 70 a$ & $p>0.999$ & $p>0.999$ & $p=0.598$ \\
\hline $60-69 a \times \geq 70 a$ & $p>0.999$ & $p>0.999$ & $p=0.179$ \\
\hline \multicolumn{4}{|l|}{ Diagnostic } \\
\hline MR tendinopathy & $6.8(5.6 ; 7.9)$ & $5.0(3.5 ; 6.5)$ & $3.1(1.6 ; 4.6)$ \\
\hline MR partial injury & $6.9(6.0 ; 7.9)$ & $4.4(3.4 ; 5.4)$ & $3.2(2.3 ; 4.2)$ \\
\hline Adhesive capsulitis & $6.3(5.8 ; 6.7)$ & $4.3(2.6 ; 6.1)$ & $2.8(1.4 ; 4.1)$ \\
\hline Calcific tendonitis & $7.6(6.6 ; 8.6)$ & $5.6(4.4 ; 6.8)$ & $4.5(2.6 ; 6.4)$ \\
\hline \multicolumn{4}{|l|}{ Comparisons } \\
\hline $\begin{array}{l}\text { MR tendinopathy } \times \\
\text { MR partial lesion }\end{array}$ & $p>0.999$ & $p>0.999$ & $p>0.999$ \\
\hline $\begin{array}{l}\text { MR tendinopathy } \times \\
\text { Adhesive capsulitis }\end{array}$ & $p>0.999$ & $p>0.999$ & $p>0.999$ \\
\hline $\begin{array}{l}\text { MR tendinopathy } \times \\
\text { Calcareous tendinitis }\end{array}$ & $p>0.999$ & $p>0.999$ & $p>0.999$ \\
\hline $\begin{array}{l}\text { MR partial lesion } \times \\
\text { Adhesive capsulitis }\end{array}$ & $p>0.999$ & $p>0.999$ & $p>0.999$ \\
\hline $\begin{array}{l}\text { MR partial lesion } x \\
\text { Calcareous tendinitis }\end{array}$ & $p>0.999$ & $p=0.849$ & $p>0.999$ \\
\hline $\begin{array}{l}\text { Adhesive capsulitis } \times \\
\text { Calcareous tendinitis }\end{array}$ & $p>0.119$ & $p>0.999$ & $p=0.856$ \\
\hline \multicolumn{4}{|l|}{ Symptoms Time } \\
\hline 3 to 6 months & $6.2(5.1 ; 7.4)$ & $3.6(2.2 ; 4.9)$ & $3.0(1.4 ; 4.6)$ \\
\hline 6 to 12 months & $6.8(5.9 ; 7.7)$ & $4.6(3.4 ; 5.7)$ & $3.1(1.8 ; 4.4)$ \\
\hline 12 to 24 months & $7.1(6.3 ; 7.9)$ & $5.8(4.4 ; 7.1)$ & $3.0(1.9 ; 4.1)$ \\
\hline more than 24 months & $7.2(6.2 ; 8.3)$ & $4.7(3.4 ; 6.0)$ & $4.4(2.8 ; 6.0)$ \\
\hline \multicolumn{4}{|l|}{ Comparisons } \\
\hline $3-6 \mathrm{~m} \times 6-12 \mathrm{~m}$ & $p>0.999$ & $p=0.975$ & $p>0.999$ \\
\hline $3-6 \mathrm{~m} \times 12-24 \mathrm{~m}$ & $p>0.999$ & $p=0.158$ & $p>0.999$ \\
\hline $3-6 \mathrm{~m} \times>24 \mathrm{~m}$ & $p>0.999$ & $p=0.975$ & $p>0.999$ \\
\hline $6-12 \mathrm{~m} \times 12-24 \mathrm{~m}$ & $p>0.999$ & $p=0.933$ & $p>0.999$ \\
\hline $6-12 m \times>24 m$ & $p>0.999$ & $p=0.975$ & $p>0.999$ \\
\hline $12-24 m \times>24 m$ & $p>0.999$ & $p=0.975$ & $p=0.999$ \\
\hline
\end{tabular}

Values expressed as estimated means and $95 \%$ confidence intervals; $p$ values corrected by the sequential Bonferroni method 
We observed that in all the diseases studied there was an improvement in VAS. In rotator cuff tendinopathy, there was an improvement from 6.8 to 3.1 at the end of the follow-up. In the partial rotator cuff injury, there was an improvement from 6.9 to 3.2 at the end of the follow-up. In the adhesive capsule there was an improvement from 6.3 to 2.8 at the end of the follow-up. In calcareous tendinitis there was an improvement from 7.6 to 4.5 at the end of the follow-up. We found no significant differences in mean VAS scores at baseline, one month and three months after treatment, between male and female, age, diagnostic, and symptom time groups ( $p>0.05$ in all comparisons in the three evaluations).

Table 5 shows the relationship between UCLA scores at baseline, one month and three months after treatment, and patient characteristics.

\begin{tabular}{|c|c|c|c|}
\hline \multirow{2}{*}{$\begin{array}{c}\text { UCLA score } \\
\text { Characteristics of patients }\end{array}$} & \multicolumn{3}{|c|}{ Evaluation } \\
\hline & Baseline & 1 month & 3 months \\
\hline \multicolumn{4}{|l|}{ Gender } \\
\hline Male $(n=13)$ & $\begin{array}{c}45.1 \\
(38.9 ; 52.2) \\
\end{array}$ & $\begin{array}{c}72.3 \\
(64.9 ; 80.6) \\
\end{array}$ & $\begin{array}{c}80.0 \\
(70.5 ; 90.8)\end{array}$ \\
\hline Female $(n=41)$ & $\begin{array}{c}42.8 \\
(39.3 ; 46.5) \\
\end{array}$ & $\begin{array}{c}67.9 \\
(62.9 ; 73.4) \\
\end{array}$ & $\begin{array}{c}72.9 \\
(66.2 ; 80.3)\end{array}$ \\
\hline \multicolumn{4}{|l|}{ Diagnostic } \\
\hline MR tendinopathy $(n=12)$ & $\begin{array}{c}41.2 \\
(34.6 ; 49.0) \\
\end{array}$ & $\begin{array}{c}69.8 \\
(61.1 ; 79.6) \\
\end{array}$ & $\begin{array}{c}74.3 \\
(61.9 ; 89.3) \\
\end{array}$ \\
\hline MR partial lesion $(n=18)$ & $\begin{array}{c}44.4 \\
(39.8 ; 49.6) \\
\end{array}$ & $\begin{array}{c}73.3 \\
(68.0 ; 79.1) \\
\end{array}$ & $\begin{array}{c}80.6 \\
(73.5 ; 88.5) \\
\end{array}$ \\
\hline Adhesive capsulite ( $n=12)$ & $\begin{array}{c}44.5 \\
(38.2 ; 51.8)\end{array}$ & $\begin{array}{c}68.8 \\
(57.3 ; 82.7)\end{array}$ & $\begin{array}{c}75.0 \\
(64.4 ; 87.4)\end{array}$ \\
\hline Calcareous tendinitis $(n=12)$ & $\begin{array}{c}42.6 \\
(36.1 ; 50.3)\end{array}$ & $\begin{array}{c}61.9 \\
(54.7 ; 70.1)\end{array}$ & $\begin{array}{c}65.5 \\
(52.2 ; 82.2)\end{array}$ \\
\hline
\end{tabular}

Values expressed as estimated means and $95 \%$ confidence intervals; $p$ values corrected by the sequential Bonferroni method.

We observed that in all diseases studied there was an improvement in the UCLA score. In rotator cuff tendinopathy, there was an improvement from 41.2 to 74.3 at the end of the follow-up. In the partial rotator cuff injury, there was an improvement from 44.4 to 80.6 at the end of the follow-up. In the adhesive capsule there was an improvement from 44.5 to 75 at the end of the follow-up. In calcareous tendinitis there was an improvement from 42.6 to 65.5 at the end of the follow-up. We found no significant differences in mean VAS scores at baseline, one month and three months after treatment, between male and female, age, diagnostic, and symptom time groups ( $p>0.05$ in all comparisons in the three evaluations).

Table 6 shows the relation between DASH scores at baseline, one month and three months after treatment, and patient characteristics. We observed that in all diseases studied there was an improvement in the DASH score. In rotator cuff tendinopathy, there was an improvement from 63 to 33.6 at the end of the follow-up. In the partial rotator cuff injury, there was an improvement from 53.2 to 33.5 at the end of the follow-up. In the adhesive capsule, there was an improvement from 58.8 to 29.7 at the end of the follow-up. In calcareous tendinitis there was an improvement from 56.2 to 39.8 at the end of the follow-up. We found no significant differences in mean VAS scores at baseline, one month and three months after treatment, between male and female, age, diagnostic, and symptom time groups ( $p>0.05$ in all comparisons in the three evaluations).
Table 6. Estimated mean values and confidence intervals $(95 \% \mathrm{Cl})$ during follow-up for the UCLA score according to the characteristics of patients with shoulder injury treated with Shockwave Therapy.

\begin{tabular}{|c|c|c|c|}
\hline \multirow{2}{*}{$\begin{array}{c}\text { UCLA score } \\
\text { Characteristics of patients }\end{array}$} & \multicolumn{3}{|c|}{ Evaluation } \\
\hline & Baseline & 1 month & 3 months \\
\hline \multicolumn{4}{|l|}{ Gender } \\
\hline Male & $\begin{array}{c}45.1 \\
(38.9 ; 52.2) \\
\end{array}$ & $\begin{array}{c}72.3 \\
(64.9 ; 80.6) \\
\end{array}$ & $\begin{array}{c}80.0 \\
(70.5 ; 90.8) \\
\end{array}$ \\
\hline Female & $\begin{array}{c}42.8 \\
(39.3 ; 46.5) \\
\end{array}$ & $\begin{array}{c}67.9 \\
(62.9 ; 73.4) \\
\end{array}$ & $\begin{array}{c}72.9 \\
(66.2 ; 80.3) \\
\end{array}$ \\
\hline \multicolumn{4}{|l|}{ Comparisons } \\
\hline Male $\times$ Female & $p=0.556$ & $p=0.361$ & $p=0.260$ \\
\hline \multicolumn{4}{|l|}{ Age group } \\
\hline 50 to 59 years & $\begin{array}{c}47.1 \\
(42.4 ; 52.2) \\
\end{array}$ & $\begin{array}{c}69.9 \\
(62.8 ; 77.9) \\
\end{array}$ & $\begin{array}{c}75.5 \\
(66.5 ; 85.7) \\
\end{array}$ \\
\hline 60 to 69 years & $\begin{array}{c}43.1 \\
(38.7 ; 48.0)\end{array}$ & $\begin{array}{c}68.7 \\
(62.5 ; 75.5) \\
\end{array}$ & $\begin{array}{c}73.9 \\
(65.7 ; 83.1)\end{array}$ \\
\hline 70 years or older & $\begin{array}{c}37.1 \\
(31.2 ; 44.2) \\
\end{array}$ & $\begin{array}{c}68.3 \\
(59.2 ; 78.8) \\
\end{array}$ & $\begin{array}{c}75.3 \\
(62.4 ; 90.7) \\
\end{array}$ \\
\hline \multicolumn{4}{|l|}{ Comparisons } \\
\hline $50-59 a \times 60-69 a$ & $p=0.287$ & $p>0.999$ & $p>0.999$ \\
\hline $50-59 a \times \geq 70 a$ & $p=0.048$ & $p>0.999$ & $p>0.999$ \\
\hline $60-69 a \times \geq 70 a$ & $p=0.287$ & $p>0.999$ & $p>0.999$ \\
\hline \multicolumn{4}{|l|}{ Diagnostic } \\
\hline MR tendinopathy & $\begin{array}{c}41.2 \\
(34.6 ; 49.0) \\
\end{array}$ & $\begin{array}{c}69.8 \\
(61.1 ; 79.6) \\
\end{array}$ & $\begin{array}{c}74.3 \\
(61.9 ; 89.3) \\
\end{array}$ \\
\hline MR partial injury & $\begin{array}{c}44.4 \\
(39.8 ; 49.6)\end{array}$ & $\begin{array}{c}73.3 \\
(68.0 ; 79.1) \\
\end{array}$ & $\begin{array}{c}80.6 \\
(73.5 ; 88.5)\end{array}$ \\
\hline Adhesive capsulitis & $\begin{array}{c}44.5 \\
(38.2 ; 51.8) \\
\end{array}$ & $\begin{array}{c}68.8 \\
(57.3 ; 82.7) \\
\end{array}$ & $\begin{array}{c}75.0 \\
(64.4 ; 87.4) \\
\end{array}$ \\
\hline Calcific tendonitis & $\begin{array}{c}42.6 \\
(36.1 ; 50.3)\end{array}$ & $\begin{array}{c}61.9 \\
(54.7 ; 70.1)\end{array}$ & $\begin{array}{c}65.5 \\
(52.2 ; 82.2) \\
\end{array}$ \\
\hline \multicolumn{4}{|l|}{ Comparisons } \\
\hline $\begin{array}{l}\text { MR tendinopathy } x \\
\text { MR partial lesion }\end{array}$ & $p>0.999$ & $p>0.999$ & $p>0.999$ \\
\hline $\begin{array}{l}\text { MR tendinopathy } \times \\
\text { Adhesive capsulitis }\end{array}$ & $p>0.999$ & $p>0.999$ & $p>0.999$ \\
\hline $\begin{array}{l}\text { MR tendinopathy } \times \\
\text { Calcareous tendinitis }\end{array}$ & $p>0.999$ & $p=0.997$ & $p>0.999$ \\
\hline $\begin{array}{l}\text { MR partial lesion } \times \\
\text { Adhesive capsulitis }\end{array}$ & $p>0.999$ & $p>0.999$ & $p>0.999$ \\
\hline $\begin{array}{l}\text { MR partial lesion } \times \\
\text { Calcareous tendinitis }\end{array}$ & $p>0.999$ & $p=0.109$ & $p=0.443$ \\
\hline $\begin{array}{l}\text { Adhesive capsulitis } \times \\
\text { Calcareous tendinitis }\end{array}$ & $p>0.999$ & $p>0.999$ & $p>0.999$ \\
\hline \multicolumn{4}{|l|}{ Symptoms Time } \\
\hline 3 to 6 months & $\begin{array}{c}47.6 \\
(43.5 ; 52.1) \\
\end{array}$ & $\begin{array}{c}72.1 \\
(65.9 ; 78.8) \\
\end{array}$ & $\begin{array}{c}80.0 \\
(66.3 ; 96.5) \\
\end{array}$ \\
\hline 6 to 12 months & $\begin{array}{c}43.6 \\
(39.1 ; 48.5) \\
\end{array}$ & $\begin{array}{c}75.9 \\
(69.7 ; 82.7) \\
\end{array}$ & $\begin{array}{c}81.6 \\
(73.1 ; 91.1) \\
\end{array}$ \\
\hline 12 to 24 months & $\begin{array}{c}43.6 \\
(37.1 ; 51.2) \\
\end{array}$ & $\begin{array}{c}60.2 \\
(51.7 ; 70.0) \\
\end{array}$ & $\begin{array}{c}70.2 \\
(60.8 ; 81.1) \\
\end{array}$ \\
\hline more than 24 months & $\begin{array}{c}39.8 \\
(33.3 ; 47.5) \\
\end{array}$ & $\begin{array}{c}69.2 \\
(60.8 ; 78.9) \\
\end{array}$ & $\begin{array}{c}67.7 \\
(55.8 ; 82.1) \\
\end{array}$ \\
\hline \multicolumn{4}{|l|}{ Comparisons } \\
\hline $3-6 m \times 6-12 m$ & $p>0.999$ & $p=0.822$ & $p>0.999$ \\
\hline $3-6 \mathrm{~m} \times 12-24 \mathrm{~m}$ & $p>0.999$ & $p=0.186$ & $p=0.902$ \\
\hline $3-6 m \times>24 m$ & $p=0.381$ & $p=0.822$ & $p=0.902$ \\
\hline $6-12 m \times 12-24 m$ & $p>0.999$ & $p=0.035$ & $p=0.514$ \\
\hline $6-12 m \times>24 m$ & $p>0.999$ & $p=0.717$ & $p=0.514$ \\
\hline $12-24 \mathrm{~m} \times>24 \mathrm{~m}$ & $p>0.999$ & $p=0.668$ & $p>0.999$ \\
\hline
\end{tabular}

Values expressed as estimated means and $95 \%$ confidence intervals; $p$ values corrected by the sequential Bonferroni method 


\section{DISCUSSION}

Shockwave therapy showed improvement in pain parameters, range of motion and functional scores in relation to the studied shoulder pathologies. In addition, no significant difference was found in the results regarding gender, age, diagnosis and previous time of symptoms, which shows that this is a treatment option that can be used in the vast majority of patients with shoulder conditions, with good results. The use of shock wave therapies in tendinopathies and partial rotator cuff injuries is not a consensus, there is still a lack of quality studies proving their effectiveness in this group of patients. ${ }^{16}$ In the study by Chou et al., ${ }^{17}$ there was a significant improvement in the pain scale and functional scores in athlete and non-athlete patients with tendinopathies and partial rotator cuff injuries undergoing treatment with shock waves. In the study by Frizziero et al., ${ }^{18}$ a comparison was made between shockwave therapy and intra-articular hyaluronic acid infiltration for the treatment of rotator cuff tendinopathy, with both showing good results. However, infiltration led to faster results and shockwave therapy led to longer lasting results. Specifically regarding rotator cuff tendinopathy compared to placebo, there are studies showing good results in favor of shockwave therapy, ${ }^{19,20}$ while others show similar results between placebo and shockwave therapies. ${ }^{21,22}$ In our study, there were good results with statistical significance in relation to shockwave therapy in all groups, although the study does not present a control group.

Regarding capsulitis, the study by Muthukrishnan, Rashid and Al-Alkharjii ${ }^{23}$ compared shockwave therapy with ultrasound therapy in the treatment of diabetic patients with adhesive capsulitis, and a significant reduction in pain and treatment costs was found in patients undergoing treatment with shock waves. In the study by Chen et al., ${ }^{24}$ there was a comparison between shockwave therapy and the use of oral steroids in the treatment of adhesive capsulitis, with both showing favorable results, with the oral steroid group showing faster results. In our study, there were favorable results both in terms of pain and improvement in functional scores in all evaluated groups.

In relation to calcifying tendonitis, there are a greater number of studies with favorable results. Duymaz and Sindel $\mathrm{l}^{25}$ compared shockwave therapy and physical therapy in the treatment of calcific tendonitis, and there was a better result in the shockwave therapy group in relation to pain, gain in range of motion and improvement in functional score. In the study by Tornese et al., ${ }^{10} \mathrm{arm}$ positions were compared (neutral position $\times$ hyperextension and medial rotation) during shockwave therapy. In the hyperextension and medial rotation group there was a higher percentage of subtotal or total reabsorption of calcium deposits (66.6\% versus $35.3 \%)$, which was positively related to clinical outcomes. In this study, patients underwent shockwave therapy sessions with the arm in a neutral position. In accordance with previous studies, ${ }^{26,27}$ ours showed an improvement in pain, range of motion and functional scores in patients with calcific tendonitis who underwent treatment with shockwave therapy.

There were good results in the four groups of diseases, both in diseases with few studies that evaluated the use of shockwave therapy as an adhesive capsule and in diseases with a greater number of studies, such as calcareous tendonitis. Another important aspect is that the results were similar in all age groups studied, showing that it is a treatment modality that can be used at different ages. Furthermore, there was no difference in the results regarding the duration of symptoms, which shows that shockwave therapy can be used in both more acute and chronic conditions.

This is the first national study to evaluate shockwave therapy in major shoulder diseases. Our study has some limitations, such as the fact that there is no comparison group (control group), however, in this first study, we wanted to evaluate the response of shockwave therapy in shoulder pathologies and, in the next step, we will carry out the comparative evaluation of this modality with other treatments. Another limitation is the three-month follow-up time, which allows an assessment of the therapeutic response but does not allow to assess whether the improvement is maintained in the long term.

\section{CONCLUSION}

Shockwave therapy proved to be an efficient and safe therapy, in the short term, in the treatment of shoulder pathologies, with improvement in pain, range of motion and functional scores in all groups of patients evaluated in the study.

AUTHORS' CONTRIBUTIONS: Each author contributed individually and significantly to the development of this article VOMO: writing, critical review and final approval; JMV: substantial contribution to the patient's data; VFO: data interpretation and shockwave therapy sessions; PHSL: writing, critical review and final approval; LCNJ: data interpretation and shockwave therapy sessions; GGA: critical review and final approval.

\section{REFERENCES}

1. Greenberg DL. Evaluation and treatment of shoulder pain. Med Clin North Am. 2014;98(3):487-504.

2. Lewis J. Rotator cuff related shoulder pain: Assessment, management and uncertainties. Man Ther. 2016;23:57-68.

3. Liu CT, Yang TF. Intra-substance steroid injection for full-thickness supraspinatus tendon rupture. BMC Musculoskelet Disord. 2019;20(1):569.

4. Shang X, Zhang Z, Pan X, Li J, Li Q. Intra-articular versus subacromial corticosteroid injection for the treatment of adhesive capsulitis: a meta-analysis and systematic review. Biomed Res Int. 2019;2019:1274790.

5. Kertzman P, Lenza M, Pedrinelli A, Ejnisman B. Tratamento por ondas de choque nas doenças musculoesqueléticas e consolidacão óssea - Análise qualitativa da literatura. Rev Bras Ortop. 2015;50(1):3-8.

6. Park C, Lee S, Yi CW, Lee K. The effects of extracorporeal shock wave therapy on frozen shoulder patients' pain and functions. J Phys Ther Sci. 2015;27(12):3659-61.

7. Verstraelen FU, In den Kleef NJHM, Jansen L, Morrenhof JW. High-energy versus low-energy extracorporeal shock wave therapy for calcifying tendinitis of the shoulder: which is superior? A meta-analysis. Clin Orthop Relat Res. 2014;472(9):2816-25

8. Ioppolo F, Rompe JD, Furia JP, Cacchio A. Clinical application of shock wave therapy (SWT) in musculoskeletal disorders. Eur J Phys Rehabil Med. 2014;50(2):217-30.
9. Saggini R, Di Stefano A, Saggini A, Bellomo RG. Clinical application of shock wave therapy musculo-skeletal disorders: part I. J Biol Regul Homeost Agents. 2015;29(3):533-45.

10. Tornese D, Mattei E, Bandi M, Zerbi A, Quaglia A, Melegati G. Arm position during extracorporeal shock wave therapy for calcifying tendinitis of the shoulder: a randomized study. Clin Rehabil. 2011;25(8):731-9.

11. Vahdatpour B, Taheri $P$, Zade AZ, Moradian S. Efficacy of extracorporeal shockwave therapy in frozen shoulder. Int J Prev Med. 2014;5(7):875-81.

12. Chou WY, Wang CJ, Wu KT, Yang YJ, Ko JY, Siu KK. Prognostic factors for the outcome of extracorporeal shockwave therapy for calcific tendinitis of the shoulder. Bone Joint J. 2017;99-B(12):1643-50.

13. Revill SI, Robinson JO, Rosen M, Hogg MI. The reliability of a linear analogue for evaluating pain. Anaesthesia. 1976;31(9):1191-8.

14. Orfale AG, Araújo PMP, Ferraz MB, Natour J. Translation into Brazilian Portuguese, cultural adaptation and evaluation of the reliability of the Disabilities of the Arm, Shoulder and Hand Questionnaire. Braz J Med Biol Res. 2005;38(2):293-302.

15. Oku EC, Andrade AP, Stadiniky SP, Carrera EF, Tellini GG. Tradução e adaptação cultural do Modified-University of California at Los Angeles Shoulder Rating Scale para a língua portuguesa. Rev Bras Reumatol. 2006;46(4):246-52.

16. Surace SJ, Deitch J, Johnston RV, Buchbinder R. Shock wave therapy for rotator cuff disease with or without calcification. Cochrane Database Syst Rev. 2020;3:CD008962. 
17. Chou WY, Wang CJ, Wu KT, Yang YJ, Cheng JH, Wang SW. Comparative outcomes of extracorporeal shockwave therapy for shoulder tendinites or partial tears of the rotator cuff in athletes and non-athletes: retrospective study. Int $J$ Surg. 2018;51:184-90.

18. Frizziero A, Vittadini F, Barazzuol M, Gasparre G, Finotti P, Meneghini A, et al. Extracorporeal shockwave therapy versus hyaluronic acid injection for the treatment of painful non-calcific rotator cuff tendinopathies: preliminar results. J Sports Med Phys Fitness. 2017;57(9):1162-8.

19. Galasso O, Amelio E, Riccelli DA, Gasparini G. Short-term outcomes of extracorporeal shock wave therapy for the treatment of chronic non-calcific tendinopathy of the supraspinatus: a double-blind, randomized, placebo-controlled trial. BMC Musculoskelet Disord. 2012;13:86

20. Li W, Zhang SX, Yang Q, Li BL, Meng QG, Guo ZG. Effect of extracorporeal shock-wave therapy for treating patients with chronic rotator cuff tendonitis. Medicine (Baltimore). 2017;96(35):e7940.

21. Kolk A, Auw Yang KG, Tamminga R, van der Hoeven $H$. Radial extracorporeal shock-wave therapy in patients with chronic rotator cuff tendinitis: a prospective randomized double-blind placebo-controlled multicenter trial. Bone Joint J. 2013;95-B(11):1521-6.
22. Efe T, Felgentreff M, Heyse TJ, Stein T, Timmesfeld N, Schmitt J, Roessler PP. Extracorporeal shock wave therapy for non-calcific supraspinatus tendinitis 10-year follow-up of a randomized placebo-controlled trial. Biomed Tech (Berl). 2014;59(5):431-7.

23. Muthukrishnan R, Rashid AA, Al-Alkharji F. The effectiveness of extracorporeal shockwave therapy for frozen shoulder in patients with diabetes: randomized control trial. J Phys Ther Sci. 2019;31(7):493-7.

24. Chen CY, Hu CC, Weng PW, Huang YM, Chiang CJ, Chen $\mathrm{CH}$, et al. Extracorporeal shockwave therapy improves short-term functional outcomes of shoulder adhesive capsulitis. J Shoulder Elbow Surg. 2014;23(12):1843-51.

25. Duymaz T, Sindel D. Comparison of radial extracorporeal shock wave therapy and traditional physiotherapy in rotator cuff calcific tendinitis treatment. Arch Rheumatol. 2019;34(3):281-7.

26. Malliaropoulos N, Thompson D, Meke M, Pyne D, Alaseirlis D, Atkinson H, et al. Individualised radial extracorporeal shock wave therapy (rESWT) for symptomatic calcific shoulder tendinopathy: a retrospective clinical study. BMC Musculoskelet Disord. 2017;18(1):513.

27. Carulli C, Tonelli F, Innocenti M, Gambardella B, Muncibi F, Innocenti M. Effectiveness of extracorporeal shockwave therapy in three major tendon diseases. J Orthop Traumatol. 2016;17(1):15-20. 